\title{
Congklak Board Game: A Way to Preserve Local Culture in Grammar Class
}

\author{
Sundari Purwaningsih ${ }^{1}$, Lystiana Nurhayat Hakim ${ }^{2}$ \\ \{sundaripurwa10@gmail.com ${ }^{1}$, tianaghea@gmail.com ${ }^{2}$ \} \\ Universitas Perjuangan Tasikmalaya ${ }^{1}$, Universitas Perjuangan Tasikmalaya ${ }^{2}$
}

\begin{abstract}
Given the fact that the existence of traditional games is in a dire need of preservation, it is pivotal for EFL teachers to engage in the preservation through English language teaching. By doing so, they help foster cultural awareness of the students and hopefully pass on the baton to them. With this in mind, it led the author to create teaching media which screams cultural element in it, and so Congklak Board Game came into being. It was developed to practice grammar exercises, focusing on simple passive, in a novel way. It was then brought into classroom practice to investigate the students' perceptions on the implementation of the media. Questionnaires (Likert scale questions); with particular reference to the physical aspects of the media, the benefits, and the students' attitude, and observation were provided to gather the data. The findings indicated that students had positive perceptions in terms of the three aforementioned criteria. The findings also lend support to extending teaching repertoire and at the same time maintain cultural heritage.
\end{abstract}

Keywords: cultural preservation, Congklak Board Game, grammar, simple passive

\section{Introduction}

As a part of culture, there is no denying that traditional games hold noble values and moral messages. They can foster cognitive, emotional and social characters. [1] Kovačević \& Opić assert that they have a therapeutic effect and the possibility of their application is great. In addition, they have the quality to improve communication skills and nonviolent conflict resolution. [2] Also, through traditional games, children learn about the rules and values of their culture. $[3,4]$

Traditional games are games passed down from one generation to another and bearing desired positive values (Bishop and Curtis, 2005). [5] Unfortunately, this passing-down kind of thing does not seem to be taking place anymore thanks to the ever-growing and ever-changing technology. They are now replaced by a massive number of digital games which is commonly believed to expose wrong values, foster individualistic behavior, and cause consumptive behavior. Besides, they lack physical movement, raise health issues, such as sight disorders, and cause agitation. [6,7]

Among many traditional games which are on the verge of disappearing in Indonesia is congklak. It is a game equipped with a wooden or plastic board with seven pairs of small holes facing each other and two big holes in the left and right sides as each player' store house. There are also seeds as many as 98 to be divide equally to the two players playing 
congklak. They are to be put in the respective holes of the player with the same number in each at the initial stage of the game. See Figure 1 below.

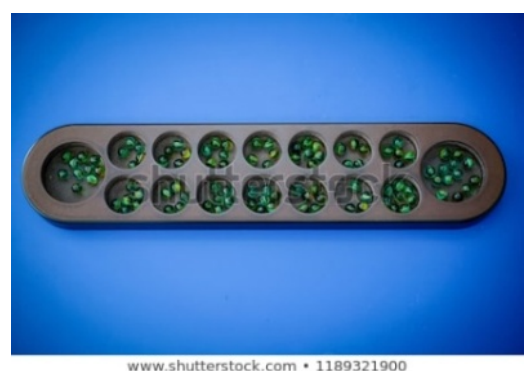

Fig. 1. Congklak (The board and the seeds)

The game is played by taking out the seeds in one of the holes and filling them in the other small holes of both players' in a clockwise manner. While moving, the player can also fill his or her store house with the seed but he or she should avoid doing so when it comes to the other player's store house. The player eventually comes to dropping the last seeds in a small hole. When it happens, he or she takes all the seeds and again repeat the procedures. The other player gets his or her turn when the seed is dropped in the player's store house. The one having the most seeds at the end of the game wins.

In his TEDx Talks entitled The Secret Meaning of "Hom Pim Pa", Zaini Alif, one of few (if not the only) Indonesian scholar of traditional games and toys, mentions that the features and how to play congklak depict the value of our daily life. Take the filling of the seed in the small hole, for example. The seven small holes represent the number of the days of the week. We can only drop one seed in each hole as it represents the necessity to live our lives in moderation. We should live and eat sufficiently on that day. We may not drop two seeds at once at a hole as it portrays excesses. We also get to fill only one seed in our bigger hole as it represents a saving. The filling of the seeds in the opponent's holes, on the other hand, teaches us to share with others. All in all, he further opines that children learn how to do business, manage their life's finances, and practice empathy with each other.

Furthermore, Sukirman mentions that not only do traditional games, such as congklak, bentengan, and hide and seek, create amusing atmosphere but they also maintain social interaction and comfort among the players. The nature of congklak which can be seen from how it is played also trains the players to be emotionally intelligence as it makes them to be more patient, honest, and sportive. [1]

Regrettably, this traditional game is on the verge of disappearing. Seldom, if not almost never, do we see youngsters or even children play congklak as their pastimes. It is not impossible that they even have no knowledge about it. Looking at how worrysome the existence of congklak is and the aforementinoed values that congklak carries with it, it will be a tremendous loss if this cultural heritage is gone for good. Hence, it is deemed necessary to create condition for this traditional game to keep existing and prevent them from oblivion. One possible action to realize this in English language teaching is to bring it to the classroom to facilitate the learning of language. Harmer asserts that games that people play at home in 
their everyday lives can be adapted for classroom use. [8] For this reason, the author came up with an idea to design congklak as teaching media in English language learning.

In this study, congklak was developed in such a way that it resembles a board game and is equipped with cards as the replacement of the seeds. That is the very reason why it is named Congklak Board Game. It was designed to be implemented in grammar class focusing on the simple passive. To stay in line with the purpose of preserving culture, the topic chosen for the materials built in Congklak Board Game was also about Indonesian culture, such as food, clothes, weapons, and arts. Students were expected to be able to produce sentences, such as 'Pempek is made from tapioca starch and fish', 'Colorful flowers are painted on the outer part of payung geulis', and the likes. Hence, simple passive was selected as the grammar focus. Besides, in the syllabus, it is also listed as one of the topics needed to be covered in grammar course in the odd semester of the academic year 2020/2021.

For years, board games have been taken advantage into a tool that promotes learning for all ages in a much more delightful way. A plethora of literature on board games has showcased their perks for learning. They are deemed useful in that they foster interactive and amusing learning ambiance and a non-threatening atmosphere where students do not have to hold back and be afraid of making mistakes, thus building their self-confidence. [9] Board games also allow learning of various contents and can motivate players to learn more about a topic. [10] In addition, board games heighten class engagement and they are more preferred to the traditional in-class worksheets. [11] Moreover, playing board games, which is a social experience, can promote the development of social and emotional skills. [12]

Therefore, the study aimed to address the question on what the students' perceptions on the implementation of Congklak Board Game in learning simple passive are. It is expected that this study, besides as a manifestation of an act of preserving local culture, may contribute to bearing some pedagogical implications.

\section{Methodology}

This is a descriptive-qualitative study seeking for students' perceptions on the implementation of Congklak Board Game in learning simple passive. It was undertaken at a private university in West Java, Indonesia. Sixteen students of third semester of English Education Department in the academic year 2019/2020 were randomly selected and agreed to be involved. There were twelve female students and six male students aged between nineteen and twenty. Questionnaires and field notes from classroom observations were used to garner the data.

The questionnaire comprised fifteen closed statements and was designed to probe students' perceptions on the implementation of Congklak Board Game to learn simple passive with particular reference to the physical aspects of the media, the benefits, and the students' attitude. The students responded to each item in a four-point Likert scale from strongly disagree (DA), disagree (D), agree (A), to strongly agree (SA). All of the statements were explained clearly to prevent the participants from misunderstanding each item. The observation technique, on the other hand, was done to gather information of the ongoing process when Congklak Board Game was implemented when teaching the grammar focus. It was a participant observation where the author intervened in the process of teaching and 
learning. The focus of the observation was on the classroom atmosphere and the students' behavior. A field note was written to gather the information.

The data were then analyzed through the process of data reduction, data display, and conclusion drawing.

Congklak Board Game was developed through research and development (R\&D) and the validity of both the media and the content has already been ensured by experts of each field. It consists of congklak board (Figure 2), task cards (Figure 3), table of verb form (Figure 4), answer key (Figure 5), and teacher's notes (Figure 6).

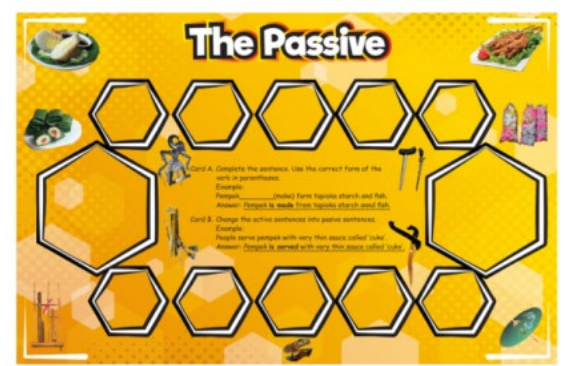

Fig. 2. Congklak board

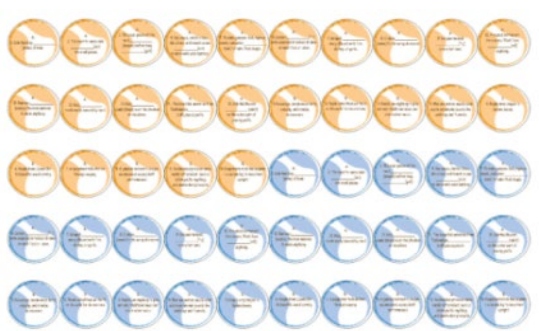

Fig. 3. Task cards

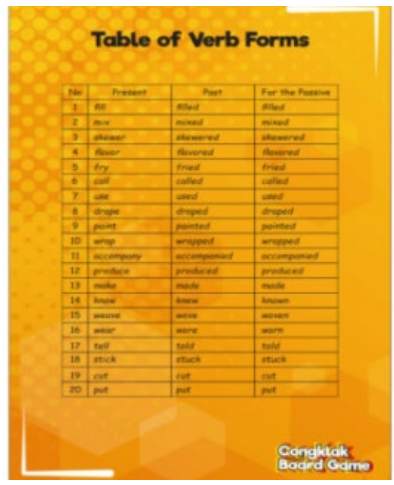

Fig. 4. Table of verb forms 


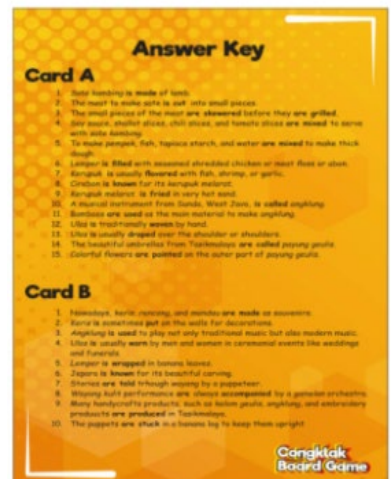

Fig. 5. Answer key

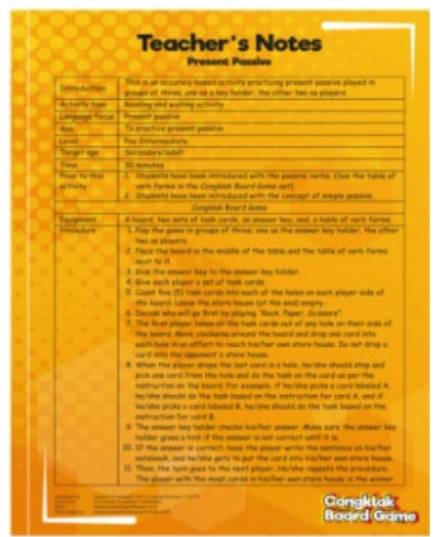

Fig. 6. Teacher's notes

In classroom teaching and learning process, it was implemented as a controlled practice of the grammar focus after it has been introduced and explained as suggested by Hadfield. [13]

\section{Finding and Discussion}

The students' perceptions of the implementation of Congklak Board Game were examined from questionnaire comprising fifteen statements. They were divided into three different aspects; physical aspects of the media, the benefits, and their attitude. Each aspect consists of five items. The findings from the questionnaire, as indicated in Table 1, revealed that, in general, students were in favor of using Congklak Board Game as a medium to learn simple passive. 
Table 1. Students' perceptions on the implementation of Congklak Board Game

\begin{tabular}{|c|c|c|c|c|c|c|}
\hline Criteria & No & Statements & SD & $\mathrm{D}$ & A & SA \\
\hline \multirow{5}{*}{$\begin{array}{l}\text { Physical } \\
\text { aspects of } \\
\text { the media }\end{array}$} & 1 & The design and layout are appealing and interesting. & & & 8 & 8 \\
\hline & 2 & The color combination is pleasing to the eye. & & & 12 & 4 \\
\hline & 3 & $\begin{array}{l}\text { The type style is not only visually appealing but also } \\
\text { legible. }\end{array}$ & & & 14 & 2 \\
\hline & 4 & The size of the each equipment is appropriate. & & 1 & 9 & 6 \\
\hline & 5 & $\begin{array}{l}\text { The instructional media is user-friendly (It's easy to } \\
\text { carry and move around). }\end{array}$ & & & 9 & 7 \\
\hline \multirow[t]{5}{*}{ Benefits } & 6 & $\begin{array}{l}\text { The use of Congklak Board Game makes me } \\
\text { understand and practice the grammar better. }\end{array}$ & & & 9 & 7 \\
\hline & 7 & $\begin{array}{l}\text { The use of Congklak Board Game makes grammar } \\
\text { lesson more enjoyable and fun. }\end{array}$ & & 1 & 8 & 7 \\
\hline & 8 & $\begin{array}{l}\text { The use of Congklak Board Game reduces stress in } \\
\text { learning the grammar. }\end{array}$ & & & 10 & 6 \\
\hline & 9 & $\begin{array}{l}\text { The use of Congklak Board Game promotes } \\
\text { interaction among me and my friends. }\end{array}$ & & & 10 & 6 \\
\hline & 10 & $\begin{array}{l}\text { The use of Congklak Board Game makes me more } \\
\text { motivated to participate in the learning process. }\end{array}$ & & & 10 & 6 \\
\hline \multirow[t]{5}{*}{ Attitude } & 11 & $\begin{array}{l}\text { The rules of how to play Congklak Board Game are } \\
\text { easy and clear. }\end{array}$ & & & 7 & 9 \\
\hline & 12 & $\begin{array}{l}\text { The use of Congklak Board Game is effective and } \\
\text { useful. }\end{array}$ & & & 8 & 8 \\
\hline & 13 & $\begin{array}{l}\text { I'm pleased about the lecturer's idea of using } \\
\text { Congklak Board Game to practice the grammar. }\end{array}$ & & & 11 & 5 \\
\hline & 14 & $\begin{array}{l}\text { I like it better to practice the grammar by using } \\
\text { Congklak Board Game than doing worksheets. }\end{array}$ & & 1 & 14 & 1 \\
\hline & 15 & $\begin{array}{l}\text { I'm pleased that Congklak Board Game makes me and } \\
\text { my friends correct grammar errors for each other. }\end{array}$ & & & 11 & 5 \\
\hline
\end{tabular}

In terms of physical aspects of the media, the majority of the students provided positive responses. Hence, media-wise, Congklak Board Game is feasible and can be utilized in teaching and learning process. This supported the validity of the experts.

In response to how the students benefit from the learning simple passive with Congklak Board Game, almost all students' responses reflected that the implementation of the game leads to better learning experience. To start with, all students opined that the use of Congklak Board Game made them understand and practice the grammar better. It means that they gained a perceived understanding of the grammar focus by playing Congklak Board Game. It so happened because while playing the game, not only did they have to keep practicing the grammar focus orally but they also had to write the sentences on their note books. In other words, the game helped them remember grammatical rules and pattern. [13]

Further, almost all students viewed Congklak Board Game as creating enjoyable and fun grammar lesson. Many studies have emphasized that games in language learning bring about this very positive impact. $[14,15,16]$ This was actually quite expected to happen because instead of them doing traditional written grammar exercises through worksheets or in a textbook, they experienced a novel way of doing them. In Congklak Board Game, grammar 
exercises were presented in a much more playful manner. They got to play game and at the same time learn the grammar focus without having to only focus on completion of the same old-school way and boring kind of thing of a worksheet or textbook exercises.

Students also perceived Congklak Board Game to be accountable to reducing stress in learning the grammar focus. The finding is consistent with a classical game theory that integrating games into language teaching and learning induces entertaining and relaxing learning atmosphere for learners which is likely to lessen their stress and anxiety in learning grammar. [17] Some previous studies yield a similar finding. [14,15,18] The reason for this to occur was due to the non-existence of intimidating vibes that traditional grammar practices usually give off. As we know, more often than not, they are followed by an activity where teachers randomly or purposefully call students' name to share their answers with the class. Such thing is not a part of Congklak Board Game. Students voluntarily took turns in solving the task cards and correcting each other for any grammatical mistakes they make with the help of the provided answer key as one of the equipment of Congklak Board Game.

In addition, they were of the opinion that Congklak Board Game promoted interaction among them. The finding about games being able to foster interaction has been revealed in a number of studies. [15,19,20] While students were playing Congklak Board Game, reading aloud, listening, and writing were practiced. As students were put in pairs or in groups of three, interaction happened when they had to read their task cards and for the other students in the same group to listen to whether or not they were doing a good job at making the sentences in the task cards into the correct form of the simple passive. This interaction resulted in them getting the opportunity to talk more, experiment and learn from mistakes, and at the same time socialize with their peers. Congklak, as a traditional game, is by nature bears the quality of fostering interaction. Hence, it's only natural for Congklak Board Game to also possess the same quality.

Lastly, it is clearly seen that from the students' perspectives, Congklak Board Game made them more motivated to participate in the learning process. The finding is in accordance with that of other studies on using games in classroom practices. [14,15,21,22] When playing Congklak Board Game, the students engaged in hands-on activities where they had to move the task cards along and dropped them in the smaller circles and the big circle of their own before eventually did the exercise in the task cards by reading them out loud for their friends to check and finally jotting them down in their note books if their answers were correct. Certainly, it was totally different from merely completing grammar exercises in a worksheet or a textbook. Besides, Congklak Board Game carries with it an element of competition where players are to collect as many task cards as possible to win the game. This element also contributed to them being more motivated than they usually were with traditional grammar exercises.

In regards to the students' attitude towards the implementation of Congklak Board Game, the finding indicated that almost all of the students had positive attitude. They approved that the rules to play Congklak Board Game were clear and easy. It is significant to note that besides having the quality of fun, clear rules were another key to a successful language game. [23]

Besides, they perceived Congklak Board Game as effective and useful. The reasons were likely attributed to the rules being easily understood, the existence of obvious relationship 
between the game and the content of the lesson, and less supervision from the teacher. Lengelling and Malarcher (as cited in Mahmoud \& Tanni) maintain that those are some requirements for a game to achieve the quality of being effective and useful. [21] Congklak Board Game in fact has the said criteria.

Moreover, they are pleased with the idea of using Congklak Board Game to practice the grammar rather than doing worksheet exercises. This is likely owing to the fact that Congklak Board Game is fun; worksheet exercises are dull and dry. Approaching grammar teaching in a serious manner is what makes grammar class dreary and responsible for inducing negative emotions towards grammar learning in the classroom.

Also, the students had positive attitude regarding Congklak Board Game facilitating them for peer correction. In other words, they were not against the very fact that Congklak Board Game is equipped with an answer key which was intended to serve the purpose of having peer correction to occur while playing the game. The reason why they like the idea is probably due to the fact that they were more comfortable with their classmates in that getting corrected by own friends was less intimidating and threatening (Rollinson as cited in Asifa). [24]

From the observation, it was crystal clear that Congklak Board Game succeeded in creating positive classroom climate. The class was lively and relaxing. It was filled with giggles and laughter from the students every now and then when it was implemented as a part of grammar practice. Also, it promoted whole class participation. Congklak Board Game is an innovation designed to also serve this very purposes. It is in line with College and University Classroom Environment Inventory (CUCEI) developed by Fraser and Treagust (as cited in Barr), that innovation, teachers utilizing unique teaching methods, activities, or assignments; involvement, teachers encouraging active student participation; and satisfaction, students enjoying the class, are some of the dimensions contributing to preferred classroom climate. [25]

Another highlight from the observation was there were some noticeable behaviors that the students displayed during the implementation of Congklak Board Game. All students were eager to do the grammar exercises while playing the game. The same behavior was not spotted when once or a few times the author used grammar exercises in a textbook for students to do. Besides, no one was seen getting distracted or playing with their cell phones. This suggested that Congklak Board Game allowed students to focus well enough to learn better. Also, there was evidence that Congklak Board Game helped shy students to participate. There were some students who always seemed so shy, if not reluctant, and gave very little contribution to classroom activities, that somehow had a change of behavior in a good way when Congklak Board Game was implemented. The finding is consistent with that of other studies on the advantages of using games in English language classroom. [21,26]

\section{Conclusions}

Congklak Board Game which was developed as an act of preserving culture through English language teaching was able to take grammar exercises to a whole new level, resulting in it earning positive perceptions from the students. The game was deemed feasible in terms of the 
physical aspects of the media, imparting pedagogical benefits, and inducing positive attitude from the students.

In terms of cultural preservation, the idea of using Congklak Board Game to practice the grammar is hoped to instill some kind of sense of responsibility in students to also participate in preserving the culture in their own way. Also, this study suggests that putting our thinking cap to explore some other ways on how to integrate our culture in our teaching may turn to have other pedagogical implications, too. By doing so, we kill two birds with one stone where we play our roles to facilitate students learning and at the same time preserve culture. The more culture is learned and presented, the more its values will increase, the less its possibility will be to vanish.

The idea of developing this teaching media came up before the pandemic and it indeed needs offline learning when implemented. Due to the pandemic, where face-to-face learning has been kept to the bare minimum, if not none, the author has not been able to investigate its effectiveness. Hence, a future study for the said purpose is suggested.

Acknowledgements The research is sponsored by Kemenristekdikti.

\section{References}

[1] Sukirman, D. Permainan tradisional jawa. Yogyakarta: Kepel Press; 2008.

[2] Kovačević T, Opić S. Contribution of traditional games to the quality of students' relations and frequency of students' socialization in primary education. Croatian Journal of Education. 2014; 16 (1): $95-112$

[3] Khalid, S. Value of traditional games. Nurture. 2008; 5: 19-21.

[4] Aypay, A. Investigating the role of traditional children's games in teaching ten universal values in Turkey. Eurasian Journal of Educational Research. 2016; 62: 283- 300.

[5] Bishop JC, Curtis M. Permainan anak-anak zaman sekarang. Jakarta: PT. Grasindo; 2005.

[6] Sălceanu, C. The influence of computer games on children's development: Exploratory study on the attitudes of parents. Procedia - Social and Behavioral Sciences. 2014; 149: 837 - 841.

[7] Zounek J, Sudický P. Heads in the cloud: Pros and cons of online learning [Internet]. [Place unknown]; 2013 [cited 2020 Nov 22]. Available from https://www.researchgate.net/publication/311807840_Heads_in_the_Cloud_Pros_and_Cons_of_On line_Learning

[8] Harmer J. The Practice of English Language Teaching ( $4^{\text {th }}$ ed). Essex: Pearson Education Limited; 2007. 4th ed. 223.

[9] Treher, E. N. Learning with board games: Tools for learning and retention [Internet]; 2011 [cited 2021 Jan 26]. Available from http://www.thelearningkey.com/pdf/Board_Games_TLKWhitePaper_May16_2011.pdf

[10] Bayeck RY. Examining board gameplay and learning: A multidisciplinary review of recent research. Simulation \& Gaming. 2020; 51(4): 411-431. https://doi.org/10.1177/1046878119901286

[11] Łodzikowski K., Jekiel M. Board games for teaching English prosody to advanced EFL learners. ELT Journal. 2019; 73(3): 275-285. https://doi.org/10.1093/elt/ccy059

[12] Hromek R, Roffey S. Promoting social and emotional learning with games. Simulation and Gaming. 2009; 40(5): 626-44. https://doi.org/10.1177/1046878109333793

[13] Hadfield J. Intermediate grammar games. Essex: Pearson Education Limited; 2003. 4.

[14] Chen IJ. Using games to promote communicative skills in language learning [Internet]. The Internet TESL Journal; 2005 [cited 2020 Nov 22]. Available from $\underline{\text { http://iteslj.org/Techniques/Chen-Games.html }}$ 
[15] Cam L, Tran TMT. An evaluation of using games in teaching English grammar for first year English-majored students at Dong Nai Technology University. International Journal of learning, Teaching and Educational Research. 2017; 16(7): 55-71.

[16] Fitriani R. Communicative game-based learning in EFL grammar class: Suggested activities and students' perception. Journals of Education and Linguistics Studies. 2018; 5(2): 171-188.

[17] Krashen S. Principles and practice in second language acquisition. Oxford: Pergamon; 1982.

[18] Yolagedili G, Arikan A. Effectiveness of using games in teaching grammar to young learners. Elementary Education Online. 2011; 10(1): 219-229.

[19] Schwartzman, R. Gaming serves as a model for improving learning. Education. 1997; 118(1): 9-18.

[20] Dickinson L. 'Have you got Mr. Bun the baker?' Problems and solutions in the use of games, role play, and simulations. English Language Teaching Journal. 1981; 35(4): 381-384.

[21] Mahmoud AAA, Tanni ZA. Using games to promote students' motivation towards learning English. Journal of Educational \& Psychological Research \& Studies. 2012; 2(5): 11-33.

[22] Laurian-Fitzgerald S. The effects of using games for English as a second language primary school learners. In I. Boldea (Ed.). The Proceedings of the International Conference Literature, Discourse and Multicultural Dialogue. 2015: 773-784.

[23] Hong L. Using games in teaching English to young learners [Internet]. The Internet TESL Journal; 2002. [cited 2020 Nov 22]. Available from http://iteslj.org/Lessons/Lin-UsingGames.html

[24] Asifa S. Peer Correction in ESL Classroom. BRAC University Journal. 2009; 6(1): 11-19.

[25] Barr JJ. Developing a positive classroom climate. IDEA Paper. 2016; 61.

[26] Ibrahim A. Advantages of using language games in teaching English as a Foreign Language in Sudan basic schools. ASRJETS. 2017; 37(1), 140-150. 